\title{
励磁機なしブラシレス三相同期発電機の解析
}

\author{
正員野 中 作太郎 (九州大) \\ 正員 袈裟丸 勝 巳(九州大) \\ 正員 堀 由 一 夫 (東京電力)
}

\section{Analysis of Brushless Three-Phase Synchronous Generator Without Exciter}

Sakutaro Nonaka, Member, Katsumi Kesamaru, Member (Kyushu University), Kazuo Horita, Member (Tokyo Electric Power Co.)

Recently a demand for small-capacity generators is increasing as electric sources in small ships and automobiles or as portable electric sources driven by engines.

It is desired that the structure of small-capacity generators is simple and robust, and that the generators are highly reliable, easily maintained and controlled.

This paper describes an analysis of the original brushless synchronous generator without exciter. The output voltage can be adjusted in the wide range by controlling the stator DC current. To analyze the characteristics of this generator, the finite element method is applied. It is found that the results of theoretical analysis agree well with the experimntal results.

キーワード：ブラシレス同期発電機, 半波整流回路, 有限要素法, 磁界解析

\section{1、まえがき}

近年, 省力化・自動化の進展, 家庭電化の普及につ れて電参機器の使用は急速に増加している。これら電 気装置を電力会社の配電線から受電しにくい場所でも 使用したい欲求, 停電時の最小限の電力確保など必然 的な要求がある。

一般に，小容量交流発電機は，夏の炎天下p冬の極 寒, 眇漠の眇ぼこりのなか, 振動の激しい車や船, 腐 食性ガスの多い工埸など榐しい舆境のもとで使用さ れ，しかも長期間保守点検を要しないメンテナンスフ リーであることを要求される。このような過酷な条件 に柇えられる発電機は，構造が簡篻堅军で，操作・保 守が容易であり，信頼性の高いことが必要である。

永久磁石形およびクローポール形同期発電機は励磁 機が不要であるが, 前者は切削加工が困難で, 高価で あり，かつ界磁調整ができないこと，後者は機械寸法 が大きく複雑になるなど問題がある。野中が開発した ブラシレス自励形学相同期発電機(1)-(3) は, 単相電機
子反作用による逆相分回転磁界を利用し, 界磁巻線に 誘導する2 倍周波数の電圧をダイオードで半波整流す ることによって自動的に界磁起磁力を得るようにした もので, 自動電圧調整器 (AVR) なしで定電圧特性 が得られるため，ポータブルエンジン発電機として国 内数社で量産され，国内外に広く普及している。しか しこの方式の発電機は定速駆動用に適している。そこ で著者らは, 可変速駆動にも適用できる固定子直流励 磁ブラシレス三相同期発電機扔よび単相同期発電機を 考案し報告した(4)-(6)。この発電機は固定子に極数の 異なる二つの巻線を施し, 回転子は各界磁巻線にダイ オードを接続して半波整流回路とするだけの簡単なブ ラシレス構造であり，3 kVA 試作発電機による実験 結果は良好な特性を示した(7)ー(9)。

柴田らは，固定子巻線に交流または直流励磁電流を 供給するブラシレス自励方式を提案している。この方 式は，回転子に主界磁巻線とこれと極数の異なる版磁 用三相巻線を施すため，構造が複雑でっった(10)(11。 最近，その改善策として，回転子は並列接続した 2 個 
の界磁巻線の中間点に単相全波整流回路を接続し，そ の出力を各界磁巻線の雨端加ら供給する方式老提案し ている(12)(13) が，回路動作上は 4 個の巻線を半波整流 回路とした構成となって招り，著者らがかねが极提案 し実用化しているブラシレス同期機(1)-(3)(7)(14) と同様 に，界磁は半波整流回路に㛿結している。従って，柴 田の方式は, 著者らが考案した前記固定子直流励磁ブ ラシレス発電機(7) と原理的に同一である。

著者らは，劯磁機なしブラシレス同期発電機の一例 として，固定子に 2 極直流励磁巻線と 4 極三相主巻線 を有する場台について報告し，近似解析により発䉓機 励磁特性を理論的に解明，更に試作発電機による㦼験 結果を示してその実用性を明確にした。また，実験に より得られた電流値を用いて有限要素法による磁界解 析を行い, 発電機内部の磁束分布を求め, 界磁電流の 大幅な脈動にもかかわらず，回転子は鎖交磁束を一定 に保持しながら回るなど，半波整流回路の有用性を示 し，発電機動作を視覚的にも明らかにしだ。

本論文は版磁機なしブラシレス 4 槡三相同期発触機 について，䇩流值も未知数とした，いわゆる“外部電 源を考慮した有限要菜法”を適用 ${ }^{(9)(15)(16)} し$ ，鉄心の飽 和，回転子ダイオードの断続を含めた発電機特性の敨 密なシミュレーションを行い, 実験結果との比較によ りその妾当性を確認した。またギャップの長さが特 性に与える影響について解明し，発電機設計の指針を 与えた。

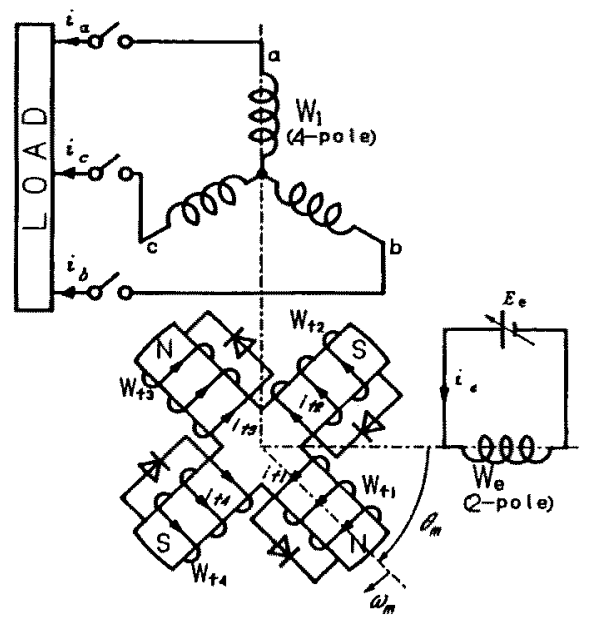

図 1 プラシレス三相同期発電機

Fig. 1. Brushless three-phase synchronous generator.

\section{2. 回路構成および構造}

〈2・1〉回路模成図1に劯磁機なしブラシレス 4 極三相同期発電機の回路を示す。固定子には 4 極三 相主菅線 $W_{1}$ とは別に2 極直流励磁巻線 $W_{e}$ を施し, 回転子は図では界磁巻線の機械巻が可能で量廒に適し た突極構造を示すが，当然円筒形回転子でもよい。回 転子の界磁巻線 $W_{f 1} \sim W_{f 4}$ にそれぞれダイオード $D_{f 1}$ $\sim D_{f 4}$ を接続して半波整流回路上する。この回転子界 磁回路方式に上れば，固定子直流压磁巻線による2亟 静止磁界は界磁電流の交流分によってほとんど打消さ れ，励磁巻線に誘導する交流電圧は小さく，固定子直 流電流による定電圧制御が容易となる特徵を有する。

$\langle 2 \cdot 2\rangle$ 構 造 図 2 は $3 \mathrm{kVA}$ 試作発電機のギ ヤップ部を誇張した断面図を示す。固定子鉄心の外径 $216 \mathrm{~mm}$, 内径 $145 \mathrm{~mm}$, ギャップの長さは $0.5 \mathrm{~mm}$ であり，鉄し積み覃は $120 \mathrm{~mm}$ である。また，試作機 の巻線仕様を表 1 に示す。

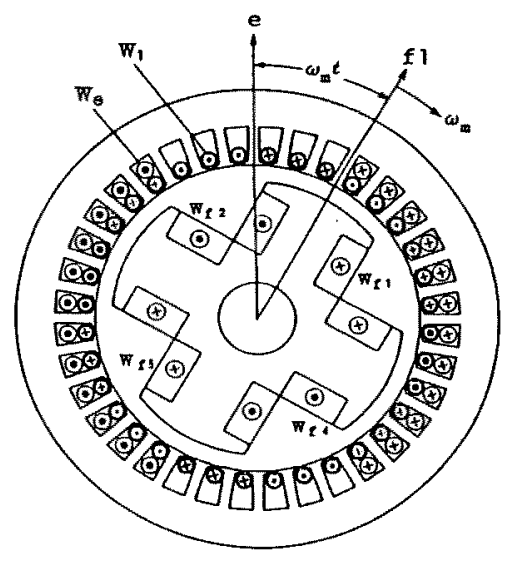

园 2 発電機断面図

Fig. 2. Cross section of generator.

表 1 試作機の巻線仕样

Table 1. Specification of generator winding.

\begin{tabular}{|c|c|c|c|}
\hline \multirow[b]{2}{*}{ 雬 } & \multicolumn{2}{|c|}{ 固定子弮線 } & \multirow{2}{*}{$\begin{array}{c}\text { 回転子巻錦 } \\
W_{n}, W_{n} \\
W_{A,} W_{A}\end{array}$} \\
\hline & $\begin{array}{c}\text { 主耉線 } \\
W_{1}\end{array}$ & $\begin{array}{c}\text { 的酸巻線 } \\
W_{e}\end{array}$ & \\
\hline 相 & 3 & 1 & - \\
\hline 極 & 4 & 2 & - \\
\hline スロット数 & 36 & 24 & - \\
\hline コイル数/相 & 6 & 12 & - \\
\hline コイル巻数 & 20 & 34 & 400 \\
\hline 直列巷数/相 & 120 & 408 & - \\
\hline 巻線の喠類 & 同心巻 & 同心巻 & 集中巷 \\
\hline
\end{tabular}




\section{3. 有限要素法による解析}

〈3.1〉仮 定発電機の有限要素法による解 析を行うにあたり，次の仮定を設りる。

（i）電磁界は軸方向に一様な二次元場である。

(ii) 洞電流，ヒスデリシスは考慮しない。

(iii）专線を流れる電流の表皮効果を無視し，電流 は導体断面を一様に流れるものとする。

(iv) 回転子は一定の定常回転速度 $\omega_{m}$ で回転す 万。

（v）4極主巻線と界破巻線のコイル端漏九磁束は 2 極直流励磁巻線の渄れ磁束に比して小さく無視でき るものとする。

〈3-2〉基礎方程式 一般に洬電流老䑾視した二 次元の電磁界の基本方程式は $(X, Y)$ 直交座標系に おいて次式で表される。

$\frac{\partial}{\partial X}\left(\nu \frac{\partial A_{z}}{\partial X}\right)+\frac{\partial}{\partial Y}\left(\nu \frac{\partial A_{z}}{\partial Y}\right)=-J_{0} \cdots \cdots$

ただし， $A_{Z}$ : ベクトルポテンシャル $A$ の $Z$

成分, $\nu$ : 磁気坻抗率, $J_{0}$ : 強制電流密度

ここで負荷電流密度, 励磁電流密度およ び界磁電流密度)

また，州1より，負荷をҮ結線の純抵抗とし，発電 機の電压方程式を立てると次式のようになる。

主巻線回路について,

$$
\left.\begin{array}{l}
\frac{d \psi_{a}}{d t}+R i_{a}=0 \\
\frac{d \psi_{b}}{d t}+R i_{b}=0 \\
\frac{d \psi_{c}}{d t}+R i_{c}=0
\end{array}\right\}
$$

ここで，R: $a, b, c$ 相各主巻線の巻線抵抗を 含んだ各相負荷抵抗， $\psi_{a}, \psi_{b}, \psi_{c}: a, b, c$ 相 各主巻線の磁束鎮交数

励磁巻線回路について，

$$
\frac{d \psi_{e}}{d t}+L_{e} \frac{d i_{e}}{d t}+R_{e} i_{e}=E_{e}
$$

ここで， $\phi_{e}$ : 励磁巻線の磁束鎖交数, $L_{e}$ : コイル端漏れインダクタンス， $R_{e}$ : 巻線抵 杭, $E_{e}$ : 㨁流励磁電圧

界磁線回路について，

$$
\left.\begin{array}{l}
\frac{d \psi_{f 1}}{d t}+R_{f} i_{f 1}=0, \frac{d \phi_{f 2}}{d t}+R_{f i_{f 2}}=0 \\
\frac{d \psi_{f 3}}{d t}+R_{f i_{f 3}}=0, \frac{d \psi_{f 4}}{d t}+R_{f i_{f 4}}=0
\end{array}\right\}
$$

ここで， $\psi_{f 1}, \psi_{f 2}, \psi_{f 3}, \psi_{f 4}$ : 各界磁巻線の磁束 鎖交数, $R_{f}$ : 各界磁巻線の抵抗
(2)〜（4)式における時間微分項を有限な微小時間 $\Delta t$ を用いて後退差分近似を行うと

例亲ば，励磁营線回路について，

$$
\begin{aligned}
& \omega_{m} \frac{\phi_{e}^{t}-\psi_{e}^{t-\Delta t}}{\Delta \theta_{m}}+R_{e} i_{e}^{t}+\omega_{m} L_{e} \frac{i_{e}^{t}-i_{e}^{t-\Delta t}}{\Delta \theta_{m}}=E_{e} \\
& こ こ て, \Delta \theta_{m}=\omega_{m} \Delta t
\end{aligned}
$$

以上の基礎方程式を基に，外部電源を考慮した有限 要素法を適用して解析を行引が, 有限要素法として解 くべきマリックスは文献 $(15) ，(16)$ と同じとなるの で,ここでは省略する。

〈3・3〉解析手法 図3に解析手順の流れ図を示 す。発電機回転子の回転は固定子スロットのコイルを 回転方向と反対方向に1スロットずつ移動することに よって模擬した。従って，スロットの高調波による影 響は考慮していない。また，鉄心の磁気飽和による非 線形性はニュートンラプソン法老用いることで考虑し た。その鉄心材料の $B-H$ 特性は磁気抵抗率 $レ と B$ の関数として，次式のような区間多項式近似を用い too

$$
\begin{aligned}
& 0 \leqq(B-0.2)^{2} \leqq 4 \text { のとき } \\
& \nu=2.873\left[86+14\left\{(B-0.2)^{2}\right\}^{5}\right\} \\
& \frac{\delta \nu}{\delta B^{2}}=201.110\left\{(B-0.2)^{2}\right\}^{4}(1-0.2 / B) \\
& (B-0.2)^{2}>4 \text { のとき } \\
& \nu=2.873\left[17,920\left\{(B-0.2)^{2}\right)-57,258\right]
\end{aligned}
$$

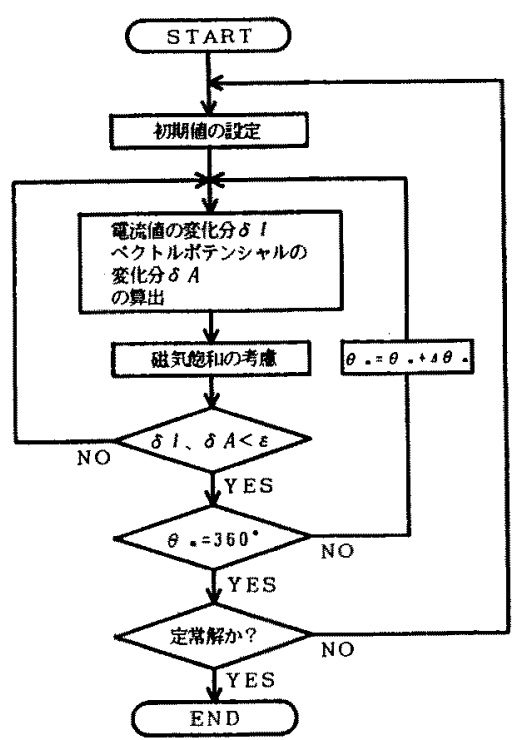

図 3 解析手順

Fig. 3. Flow chart for analysis. 


$$
\frac{\delta \nu}{\delta B^{2}}=\{17,920 \times 2,873(1-0.2 / B)
$$

回転子ダイオードの境界条件は, 巻線誘起電圧がダ

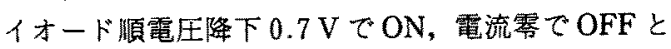
して，各界磁回路の断続状態を考虑した。

\section{4. 解析結果}

モデルの有限要菜分割に際して，磁束の非対称性を 考虑して発電機全領域について，図 4 のように一次三 角形要素によって要素数 1,960 , 節点数 1,028 に分割 した。

発電機の定数は以下のようである：

$$
R_{e}=7.0 \Omega, L_{e}=0.01 \mathrm{H}, R_{f}=3.0 \Omega
$$

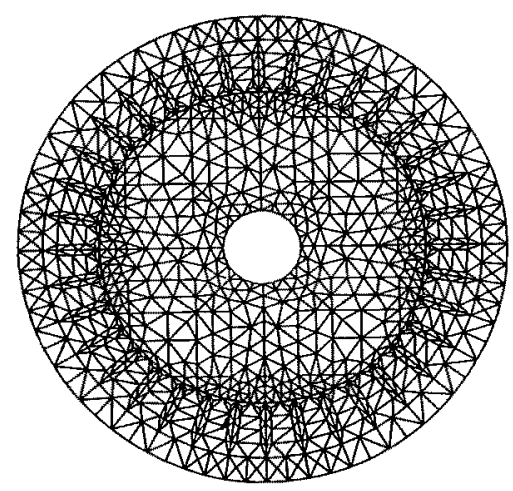

园 4 分割図

Fig. 4. Finite element subdivision.

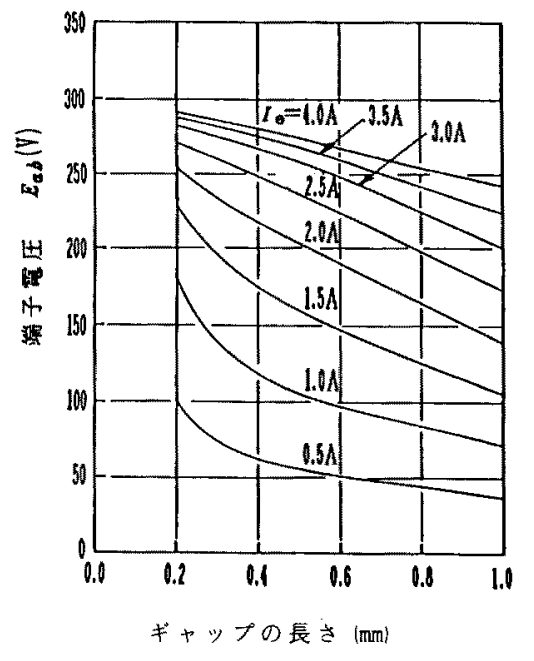

国 5 無負荷電生特性

Fig. 5. No-load characteristics.
図 5 は発電機ギャップの長さに対する無負荷電圧の 変化を示し, 端子電圧 $E_{a b}$ は, 励磁電流 $I_{e}$ が約 $2 \mathrm{~A}$ 以下ではギャップの長さにほぼ比例して减少する が，それ以上では磁気飽和に起因して単調に隇少す る。無負荷時の磁束分布を $\theta_{m}=0,40^{\circ}$ の各場合につ いて図 6 に示す。界磁電流は半波整流回路を流れるた め大幅に脈動するが，界磁磁束は変化せずほほ定に 保持されているのが確認できる。

図 7 は無負荷時における回転子鎖交磁束, 固定子鎖 交磁束枋よび電上の波形を示す。回転子界磁磁束 $\psi_{f 1}$ 一敉4 は図 6 の磁束行布で示したように，ほほ一定に 保持されているが，図 7 から界磁抵抗によるかずかな 隇衰が見られる。
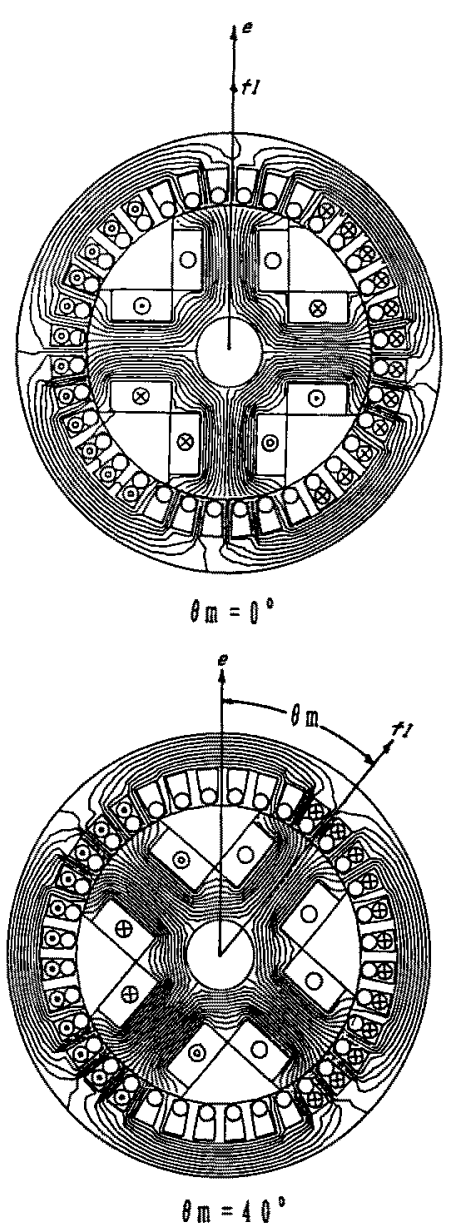

図 6 回転角に対する無負荷磁束分布 Fig. 6. Flux distributions with rotor angles at no-load. 


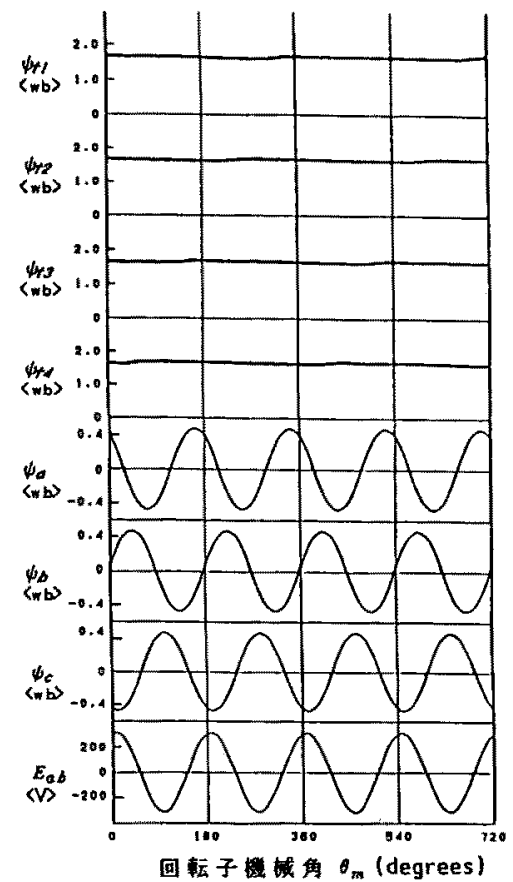

図 7 無負荷時における磁束鎖交数と 電圧の波形

Fig. 7. Waveforms of flux linkages and voltage at no-load.

図 8 は $3 \mathrm{~kW}$ 負荷時のギャップの長さ $0.2,0.5$, $1.0 \mathrm{~mm}$ の备場合の電流波形を示す。界磁電流の波形 から、ギャップの長さにかかわらず $\theta_{n}$ のほぼ $90^{\circ} 区$ 間に扔いて、ダイオード1個は非導通となることがわ かる。しかし，ダイオードが導通している三つの界磁 巻線によって非導通の界磁線の磁束が一定に保持さ 路 ${ }^{(7)}$ 。

\section{5. 実験結果との比較}

図 9 は励磁電流 $I_{e}$ を変化して求めた無負荷飽和曲 線を示す。界磁電流の直流平均值 $\overline{i_{f 1}}\left(\fallingdotseq \overline{i_{f 2}} \fallingdotseq \overline{i_{f 3}} \fallingdotseq \overline{i_{f 4}}\right)$ は励磁電流 $I_{e}$ に比例して变化し，奏験機のギャップ の長さは $0.5 \mathrm{~mm}$ であるが，理論值は実験值とよく一 致している。

图 10 は電流 $I_{e}$ を2.1A 一定とした場合の負荷特性 を示す。界磁電流は負荷ちよびギャップの長さとは無 関係に一定となり, 電圧 $E_{a b}$ はギャップの舆さが小 さいほど金下特性となる。

図11は電圧 $E_{a b}=220 \mathrm{~V}$ 一定となるように電流 $I_{e}$ を調整した場合の負荷特性を示す。ギャップが大きい 場合，矿磁電流 $I_{e}$ の変化割合は小さくてすむが，そ

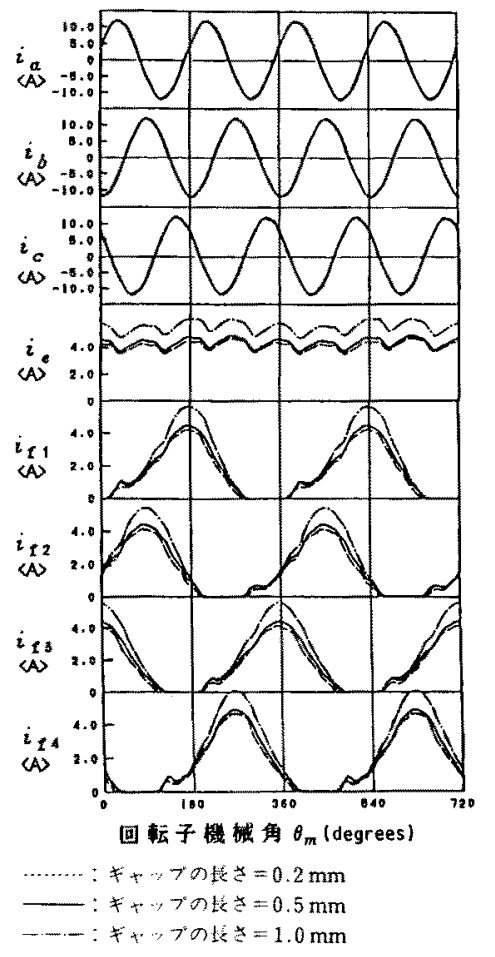

图 8 定整負荷時の各部電流波形

Fig. 8. Waveforms of currents with some values of gap length at full load.

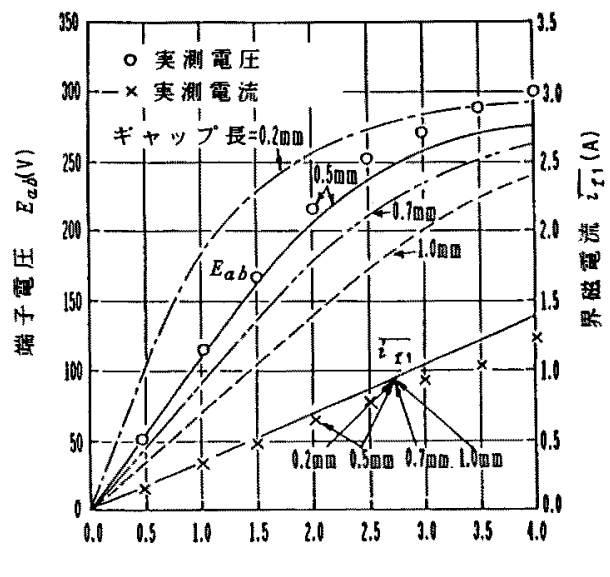

磁酸流 $I_{\mathrm{e}}(\mathrm{A})$

图 9 無急荷飽和曲線

Fig. 9. No-load saturation curves.

の値は全体的に大きくなる。すなわち、ギャップの長 きを大きくすることによって電機子反作用は低減でき るが，同一急荷に対して所要研磁電流，従って界磁電 


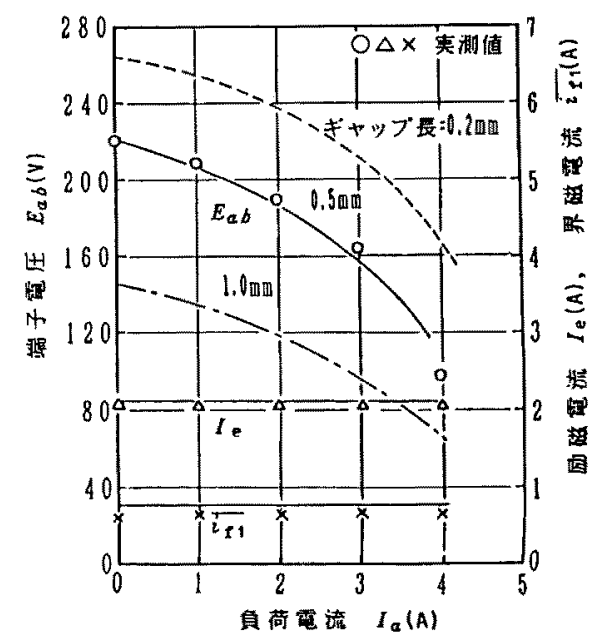

図 10 負荷特性 $\left(I_{e}=2.1 \mathrm{~A}\right.$ 一定)

Fig. 10. Load characteristics $\left(I_{e}=2.1 \mathrm{~A}\right.$ constant).

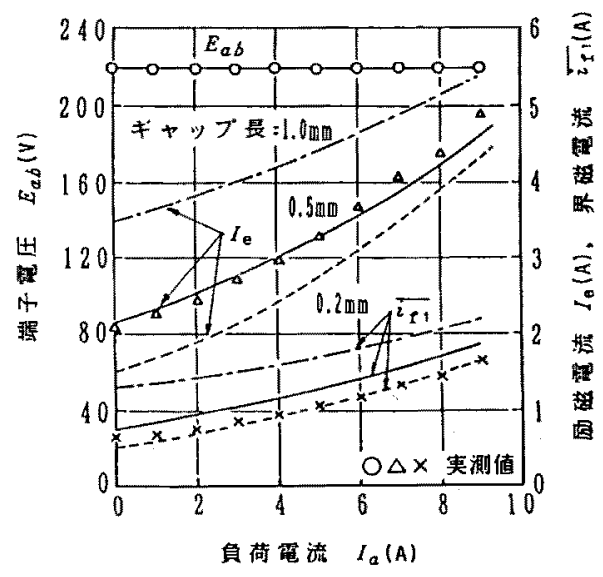

図 11 鿓荷特性 $\left(E_{a b}=220 \mathrm{~V}\right.$ 一定)

Fig. 11. Load characterisiics $\left(E_{a b}=220 \mathrm{~V}\right.$ constant).

流も增大し，銅損が増加する。例之ば，定格負荷時に

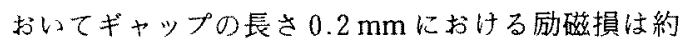
$130 \mathrm{~W}$,これに対し $1.0 \mathrm{~mm}$ での損失は約 $240 \mathrm{~W}$ と ほほ倍增する。従って, ギャップの長さは機械的に可 能な限り小さく設計することが肝要である。

図 12 は $3 \mathrm{~kW}$ 負荷時の各部電流の測定波形を示す。 本実験機㹥斜めスロットを採用していないため，ス口 ットリプルが現れているが、これを除けば図8の理論 波形とよく一致することがわかる。

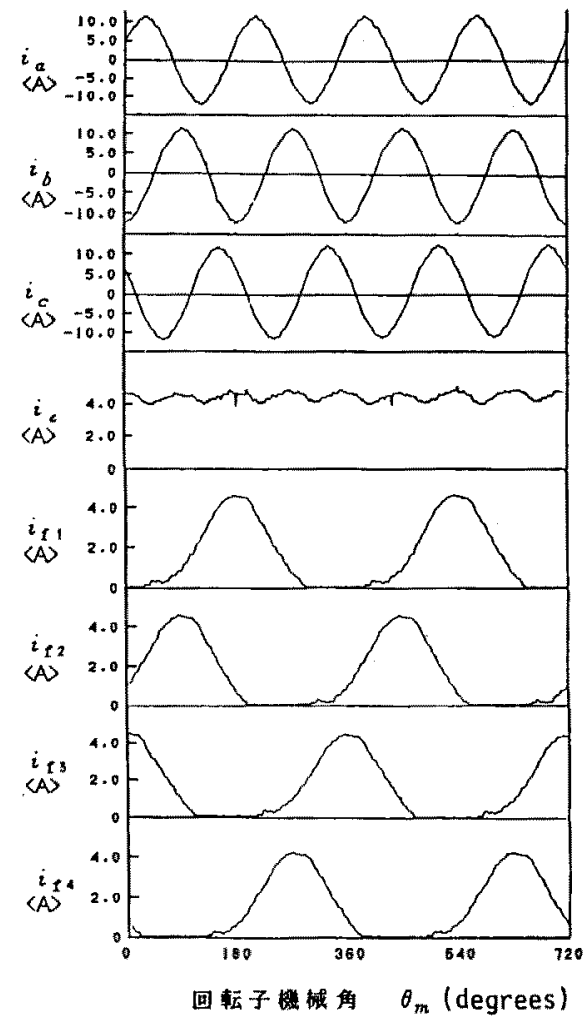

図 12 定格負荷時の実測波形

Fig. 12. Measured waveforms at full load.

\section{6.むすび}

以上，本論文は励磁機なしブラシレス 4 極三相同期 発電機について, 有限要素法を適用し, 鉄心の飽和, 回転子ダイオードの断続を含めた発電機特性の䇴密な 解析を行い,その結果を示した。特に, ギャップの長 さが特性に与える影響について解明し，この種の自励 発電機ではギャップの長さは機械的に許される限り小 さく設計することが望ましいことを確認した。

な扔，本発電機岵定回転のエンジン発電機ばかりで なく, 風力発電やミニ水力発電のように広範囲に速度 が変動する用途や，メンテナンスフリーを要求される 用途に好適と考えられる。(平成 3 年 7 月 31 日受付)

\section{文献}

（1）原田・野中：个自尉型単相同期発電機了，特許第 244444 号 (特公昭 33-2367)

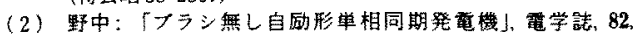
627 (昭 37-4)

（3）野中・车田：「ブラシなし自行形単相同期発䉓㙨の特性」, 同 


\section{上, 91，1291（昭 46-7）}

（4）野中・袈装丸：「フララシレス三相同期発電機の一方式」, 昭 56 電気学会全大, No. 701

（5）野中・袈装丸・藤井：「励礠機なしフララシレス他励三相同期 発電機とその特性」, 電気学会回転機研資, RM-82-5 (昭 57)

(6) S. Nonaka \& K. Kesamaru: "Brushless Separately Excited Three-Phase Synchronous Generator without Exciter", International Conference on Electrical Machines, Budapest, p. 446 (1982)

（7）野中・袈装丸：「励磁機なしブラシレス三相同期発電機」, 電 学論 $B, 105,851$ (昭 60-10)

(8) S. Nonaka \& K. Kesamaru: "Analysis of Voltage. adjustable Brushless Synchronous Generator without Ex citer", IEEE Trans. Industr. Applic., IA-25 No. 1, 126 (1989)

(9) S. Nonaka \& K. Kesamaru: "Magnetic Field Analysis of Brushless 4-pole Single-phase Synchronous Generator without Exciter", International Conference on Electrical Machines, Cambridge, p. 1177 (1990)

(10) F. Shibata \& T. Fuk ami : "A Brushless, Self-Excited Polyphase Synchronous Generator", IEEE Trans. Power Apparatus Syst.. PAS-102, No. 8, 2413 (1983)

(11) 柴田・直江:「ブラシレス自励正弦波単相同期発電機」, 電学 論 $\mathrm{D}, 109,251$ (平元-4)

（12）柴田・深見：「固定子電機子巻線を直流励磁するブラシレス 单相同期電動機」, 同上 D, 109, 865 (平元-11)

（13）柴田・直江：「半波整流平衡二相界磁巻線をもつブラシレス 自励正弦波単相同期発電機の基礎特性」, 同上D, 110 , 1005 (平 2-9)

（14）野中:「自励型三相同期発電機」, 特許第 272321 号(特公 昭 35-11263)

（15）中田・高橋・藤原：「外部電源を考慮した有限要素法による 单相誘導電動機の解析」, 電気学会回転機・静止器合同研資, BM-81-40; SA-81-30(昭 56)

(16) T. Nakata \& N. Takahashi : "Direct Finite Element Analysis of Flux and Current Distributions under Specified Conditions", IEEE Trans. Magnetics, MAG-18, 235(1982)

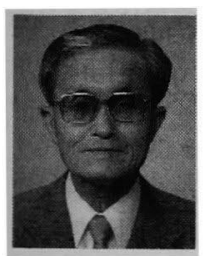

\section{野 中 作太郎 (正員)}

昭和 3 年 11 月 12 日生。 27 年 3 月九 州大学工学部電気工学科卒業。29 年 4 月同大学工学部講師, 30 年 6 月同助教 授, 40 年 4 月九州工業大学教授, 42 年

4 月九州大学工学部教授, 電気機器学講座担当。平成元年 4 月〜 3 年 3 月九州大学工学部附属超伝導マグネット研究 センター長併任, 平成 2 年 6 月改組により電気工学科エネ ルギー変換機器工学講座担当, 現在に至る。この間, ブラ シレス単相同期発電機, 正弦波入出力 PWM 電流形コン パーターインパータシステム, 超電導モータ, 新交通シス テム用リニア誘導モー夕, 磁気浮上式鉄道などの研究に従 事。工学博士。 46 年電気学会論文賞, 1985 年 IEEE/IAS 論文賞受賞。5 8 年度電気学会九州支部長。1 1980 年以降電 気機械に関する国際会議 (ICEM) 運営委員会委員, 1986 年以降 IEEE/IAS 電気機械委員会委員。パワーエレクト ロニクス研究会会員。

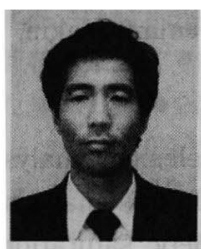

袈婆丸 勝 巳 (正員)

昭和 24 年 6 月 27 日生。 47 年 3 月佐 賀大学理工学部電気工学科卒業。52 年 3 月九州大学大学院工学研究科電気工学 専攻博士課程修了。同年 4 月同大学工学 部助手, 平成元年 7 月同助教授, 現在に至る。ブラシレス 同期発電機に関する研究, 磁界解析に関する研究に従事。 工学博士。

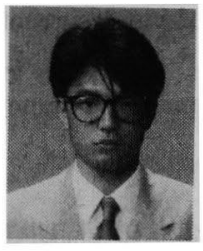

現在に至る。
堀田一夫 (正員)

昭和 42 年 1 月 10 日生。平成元年鹿児 島大学工学部電気工学科卒業。 3 年九州 大学大学院工学研究科電気工学専攻修士 課程修了。同年 4 月東京電力 (株) 入社, 